\title{
Late Ordovician-Early Silurian trace fossils from the Matapedia Group, Tobique River, western New Brunswick, Canada. II. Additional discoveries with descriptions and comments
}

\author{
R.K. Pickerill \\ Department of Geology, University of New Brunswick \\ Fredericton, New Brunswick E3B 5A3 \\ L.R. Fyffe \\ Department of Natural Resources and Energy, Minerals and Energy Division \\ Fredericton, New Brunswick E3B SHI \\ and \\ W.H. Forbes \\ Department of Geology, University of Maine at Presque Isle \\ Maine 04769 U.S.A. \\ Date Received January 10, 1988 \\ Date Accepted May 26, 1988
}

\begin{abstract}
Previous recordings of Late Ordovician-Early Silurian flysch trace fossils (13 ichnogenera, 15 ichnospecies) from slope deposits of the Matapedia Basin at a single site on the Tobique River, western New Brunswick, are supplemented by the addition of 9 newly discovered ichnogenera (12 ichnospecies). These are:- Circulichnis montanus, Cruziana problematica, Cruziana cf. stromnessa, Diplichnites ichnosp., Megagrapton irregulare, Monocraterion ichnosp., Phycosiphon incertum, Rusophycus didymus, Rusophycus ichnosp. types A and B, Scolicia ichnosp, and Tuberculichnus ichnosp. The traces are poorly preserved and occur only in low numbers compared to previously documented forms. Nevertheless, the meticulous sampling procedures adopted at the site emphasize the need for detailed collecting, before drawing conclusions regarding diversity models, stratigraphic distribution, etc., of trace fossils. Of these new forms only Diplichnites ichnosp. has previously been recorded from the Matapedia Basin in the partially coeval Lower Silurian Siegas Formation. Tuberculichnus ichnosp. is recorded for the first time in North America. The combined total of 22 ichnogenera (27 ichnospecies) from the Tobique River represents the most diverse ichnocoenosis yet reported from a single ancient slope deposit. The occurrence of several more typically shallow-water ichnogenera (e.g., Cruziana, Diplichnites, Monocraterion and Rusophycus) suggests that, at least in the Early Palaeozoic, caution must be exercised in their utilization as distinctive facies or environmental indicators.
\end{abstract}

9 nouveaux ichnogenres (12 ichnoespèces) s'ajoutent à ceux déjà répertoriés ( 13 ichnogenres, 15 ichnoespèces) en un site unique localisé sur la rivière Tobique, dans l'ouest du Nouveau-Brunswick, dans des sédiments tardiordoviciens è éosiluriens accumulés sur le talus continental du Bassin de Matapedia. Ce sont: Circulichnis montanus, Cruziana problematica, Cruziana cf. stromnessa, Diplichnites ichnosp., Megagrapton irregulare, Monocraterion ichnosp., Phycosiphon incertum, Rusophycus didymus, Rusophycus ichnospp, types A et B, Scolicia ichnosp. et Tuberculichnus ichnosp. Ces demières sont mal conservées et relativement rares par rapport aux formes déjà connues. Néanmoins, le dépouillement méticuleux utilisé à ce site démontre la nécessité d'une collecte détaillée av ant de tirer des conclusions quant aux modèles de diversité, à la distribution stratigraphique, etc., des traces fossiles. De ces nouvelles formes, seule Diplichinites ichnosp. est déjà connue dans le Bassin de Matapedia, soit dans la Formation silurienne inférieure et en partie synchrone de Siegas. On recense Tuberculichnus ichnosp. pour la première fois en Amérique du Nord. Le total combiné de 22 ichnogenres (27 ichnoespèces) présents sur la rivière Tobique représente l'ichnocoenose la plus diverse jamais répertoriée dans un seul dépôt de talus. La présence de plusieurs ichnogenres typiques d'une faible tranche d'eau (e.g., Cruziana, Diplichnites, Monocraterion et Rusophycus) démontre que la prudence est de mise lors de leur utilisation à titre d'indicateurs de faciès on de milieu, tout particulièrement à l'Eopaléozoique.

[Traduit par le joumal]

\section{INTRODUCTION}

In a recent publication (Pickerill et al., 1987) we documented a relatively diverse Late Ordovician-Early Silurian flysch ichnocoenosis from slope deposits of the Matapedia Group on the Tobique River, western New Brunswick. In that publication we described 13 ichnogenera (15 ichnospecies) from a single site (Fig. 1), noting that the entire assemblage represented the most 

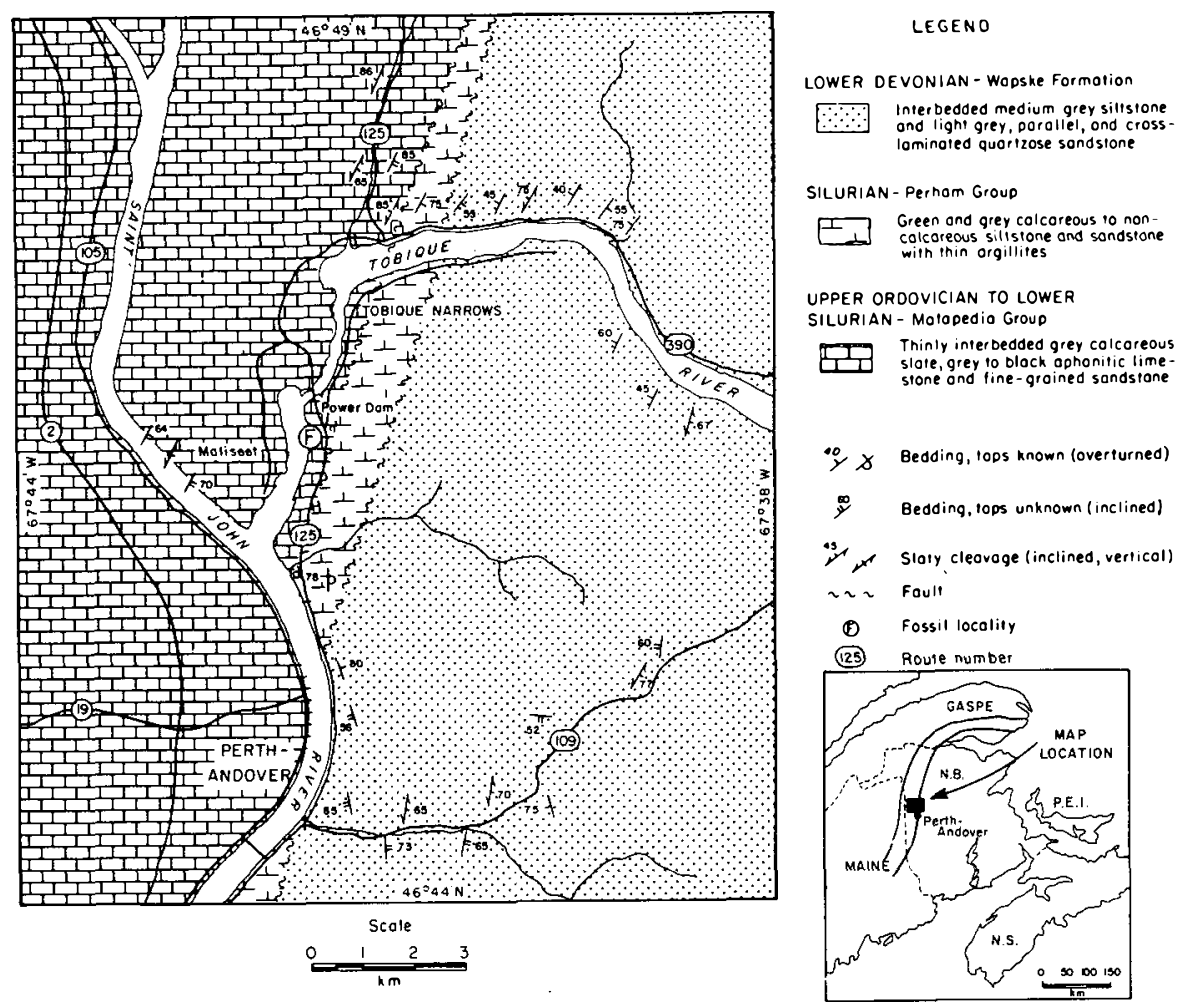

Fig. 1. Location and simplified geological map of the Perth-Andover area, western New Brunswick. In the small inset map the Matapedia Basin is outlined by a stippled omament.

diverse ichnocoenosis formally recorded from Lower Palaeozoic slope deposits. As previously reported, the site (Fig. 1) is situated on the planned location of a trout and salmon aquaculture centre. This construction has now been initiated and its eventual completion will result in coverage of many of the exposed strata and removal of the associated and considerable talus deposits from which most of the trace fossils were collected.

In view of its ichnological importance, the New Brunswick Department of Natural Resources and Energy provided a minority group summer contract to Donna and Regina Pearly, who for three months systematically collected, sorted (under supervision) and donated the material from the site to us for further study. The vast amount of productive material yielded many further examples of all the previously reported ichnogenera (see Pickerill et al., 1987, and comments, discussion and conclusions section herein). More importantly, it revealed an additional 9 ichnogenera (12 ichnospecies) not previously discovered by us. The purpose of this paper is therefore to document, particularly systematically, these previously unreported ichnogenera and, as a corollary, to briefly comment on the importance and relevance of these discoveries with respect to several facets of ichnological research.

\section{SYSTEMATIC PALICHNOLOGY}

As in our previous paper (Pickerill et al., 1987) we describe the trace fossils in alphabetical order rather than in any formal morphological or behavioural groupings. For brevity, extensive discussion on particular ichnospecies has been minimized and only pertinent observations, conclusions and/or additional relevant literature have been included. Cleavage formation, pressure solution activity and, presumably, primary compaction of the trace fossils at the Tobique site have effected considerable deformation of most specimens but size measurements have not been corrected for concomitant strain. Additionally, metamorphism has contributed to their generally poor preservation and photographic reproducibility. All figured material has therefore been prepared employing one or, more commonly, a combination of the following methods:- (a) immersion in dilute (10\%) hydrofluoric acid for 1-2 minutes, (b) whitening with sublimate of ammonium chloride or (c) enhancement with removable marker ink. All figured material is currently housed in the Department of Geology, University of New Brunswick. Once ichnological studies of the Matapedia Group has been completed, the material will be housed with the Geological Survey of Canada in Ottawa.

\section{Ichnogenus Circulichnis Vialov, 1971}

\section{Circulichnis montanus Vialov, 1971}

(Fig. 2a)

\section{Description}

Seven specimens, poorly preserved in convex hyporelief on siltstone soles or concave or convex epirelief on upper surfaces. Each trace consists of a circular or elliptical burrow, locally collapsed, with a structureless fill identical in grain size to 

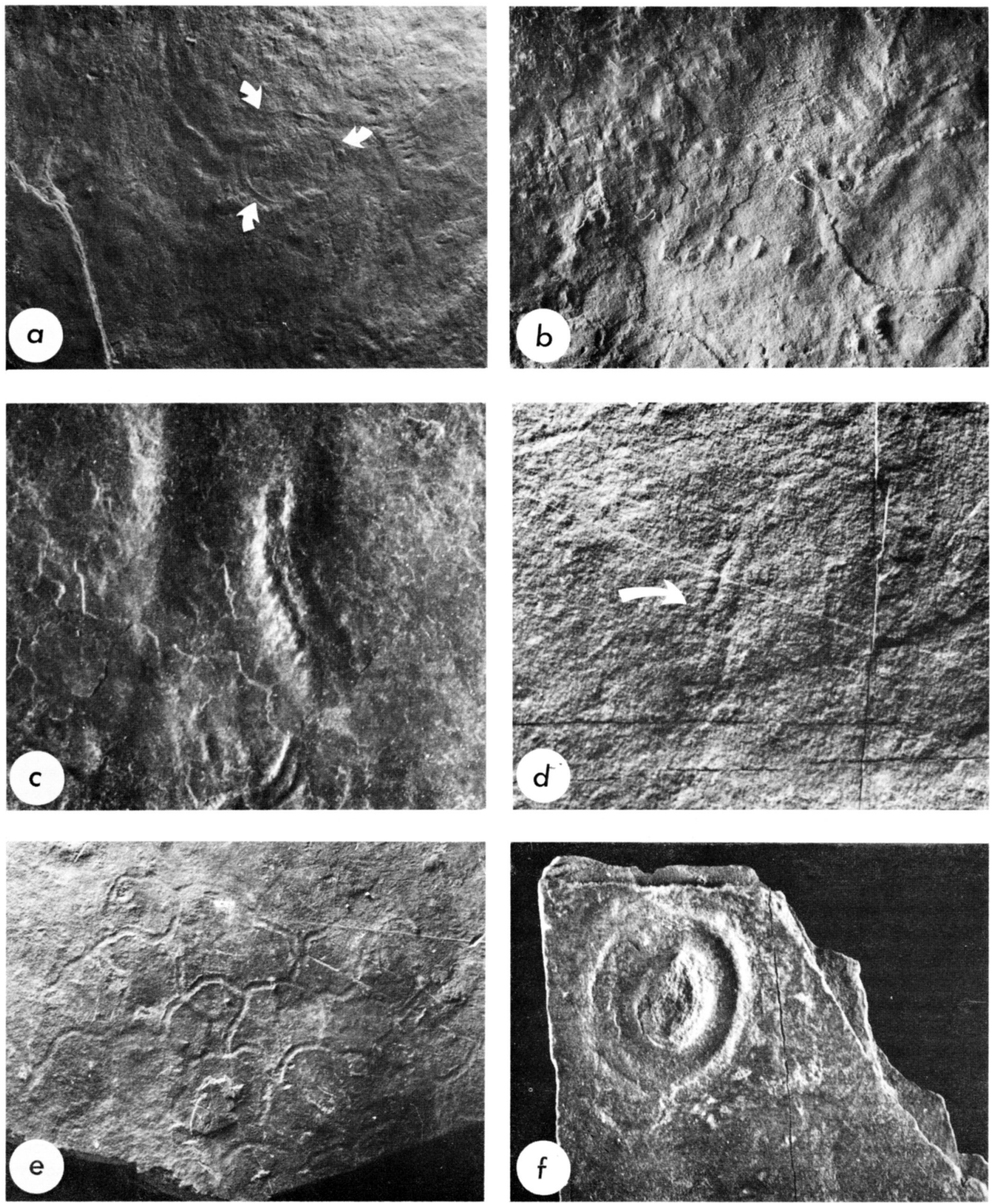

Fig. 2. a. Circulichnis montanus (arrowed) preserved in convex hyporelief, $x 1.0$. b. Diplichnites ichnosp. preserved in convex hyporelief. Track runs approximately E-W, x1.3. c. Cruziana cf. stromnessa preserved in convex hyporelief, x3.1. d. Cruziana problematica (arrowed) preserved in convex hyporelief, x2.0. e. Megagrapton irregulare preserved in concave epirelief, x0.6. f. Monocraterion ichnosp. funnel preserved in convex epirelief, $x 1.6$. 
enclosing sediment. Largest burrow system is $1.9 \mathrm{~cm}$ in width with burrow diameter of $1.9 \mathrm{~mm}$; smallest is $0.9 \mathrm{~cm}$ in width with burrow diameter of $0.8 \mathrm{~mm}$. Individual burrows are elliptical in cross-section due to compaction.

\section{Remarks}

Detailed remarks with respect to the origin and stratigraphic range of Circulichnis have been made by Fillion and Pickerill (1984, in press a). Although a eurybathic form, it has more often been reported from deep-water flysch. Its recording from the Tobique site represents the first from the Matapedia Basin of Fyffe et al. (1981), though because of its simple morphology we anticipate further discoveries from elsewhere in the basin.

\section{Ichnogenus Cruziana d'Orbigny, 1842}

\section{Cruziana problematica (Schindewolf, 1921)}

(Fig. 2d)

\section{Description}

Single, poorly preserved, $20 \mathrm{~mm}$ long, curved bilobate sole trace. Lobes are not deeply impressed; each is $2 \mathrm{~mm}$ wide with a narrow ( $<0.5 \mathrm{~mm}$ wide) groove separating them along the length of the trace. Each lobe possesses faint scratch marks; each approximately $1 \mathrm{~mm}$ apart, oriented normal to the trace axis and crossing the entire lobe.

\section{Cruziana cf. stromnessa (Trewin, 1976)}

(Fig. 2c)

\section{Description}

Single, $15 \mathrm{~mm}$ long, $4 \mathrm{~mm}$ wide curved bilobate sole trace, relatively deeply impressed. Each $2 \mathrm{~mm}$ wide lobe is separated by a narrow $(<0.5 \mathrm{~mm}$ wide) groove and possesses dot-like scratch marks, each approximately $1 \mathrm{~mm}$ apart, oriented at an angle of $60-80^{\circ}$ to the trace axis and crossing the entire lobe.

\section{Remarks}

Both specimens are relatively small and narrow compared with more typical examples of Cruziana and are more akin to what many previous, and indeed present, authors have referred to as Isopodichnus Bomemann, 1889. However, we agree with the reasoning of Bromley and Asgaard (1979) to include Isopodichnus within Cruziana as realistically the only essential differences between these ichnogenera are, morphologically, in accessory features (sensu Fürsich, 1974), which should be employed only for classification at the ichnospecific level. One specimen can clearly be diagnosed as $C$. problematica, which is characterized by being less than $7 \mathrm{~mm}$ in width and possessing transverse striations (see Fillion and Pickerill, in press a). The second cannot be confidently assigned to a distinct ichnospecies but closely resembles and hence is compared to $C$. stromnessa as described by Trewin (1976). Additionally, this latter specimen is virtually identical to the unnamed trace fossil figured by Dahmer (1934, plate 8, fig. 10) from the Early Devonian of southern Germany). Although both $C$. problematica and $C$. stromnessa have previously been recorded from a variety of nonmarine and shallow-marine Palaeozoic sequences (see Fillion and Pickerill, in press a), to our knowledge they have never previously been reported from deep-water slope sequences.

Ichnogenus Diplichnites Dawson, 1873

\section{Diplichnites ichnosp.}

(Fig. 2b)

\section{Description}

Simple, straight to gently curved trackways preserved in convex hyporelief on siltstone soles. Each track consists of two parallel series of equally spaced and approximately equal-sized smooth, regular and straight imprints; individual imprints are elongate, $2-3 \mathrm{~mm}$ in length and $1 \mathrm{~mm}$ or less in width, with their long axes oriented at an angle of approximately $40^{\circ}$ to the track axis. Individual track sets (sensu Osgood, 1970) are up to $2 \mathrm{~cm}$ in maximum (and total) width and $6 \mathrm{~cm}$ in maximum observed length.

\section{Remarks}

Diplichnites is a morphologically simple trackway but restudy of its 'forms', 'types' and ichnospecies of various authors (e.g., Osgood, 1970; Osgood and Drennen, 1975; Fillion and Pickerill, in press a) is still deemed necessary for any meaningful ichnospecific assignment. It is morphologically similar to $D i$ morphichnus Seilacher, 1955, an arthropod track previously reported by us (Pickerill et al., 1987) from the Tobique site, but differs by possessing approximately equal-sized (length) imprints on each side of the track. Though more typically previously reported from shallow-water marine sequences it has also previously been reported from deep-water strata (e.g., Pickerill, 1981). The recording herein is its first from the Matapedia Group.

Ichnogenus Megagrapton Ksią̧ziewicz, 1968

\section{Megagrapton irregulare Ksiażkiewicz, 1968}

(Fig. 2e)

\section{Description}

Single specimen, poorly preserved in concave epirelief on the upper surface of a thinly-bedded slate. The specimen covers an area of $10 \times 8 \mathrm{~cm}^{2}$ and consists of an irregular network of variably shaped and sized, but typically relatively large, nets of interconnected polygonal (4-8 sides) ?burrow segments. Individual segments are consistently $2 \mathrm{~mm}$ wide, with slightly elevated and well-defined external margins differentiated by colour rather than any difference in grain size. Branching between individual polygons is characteristically at irregular 
intervals and at approximately right angles, though because of the shape of individual segments (straight, curved or slightly sinuous) these angles vary from $40^{\circ}$ to $90^{\circ}$.

\section{Remarks}

Megagrapton is a distinctive graphoglyptid trace fossil (Seilacher, 1977a). Graphoglyptids are almost universally preserved as positive features in convex hyporelief on bedding plane soles, though rare exceptions have been reported (e.g., Seilacher, 1977a). This particular example therefore represents a unique and fortuitous example of chance preservation. Additionally, it also demonstrates that at least some graphoglyptids were either open burrows prior to casting (cf. Seilacher, 1977a) or, in fact, represent surface traces. Irrespective of origin, the trace can be clearly assigned to $M$. irregulare, which is characterized by its irregularly shaped polygonal nets of different size and common right angle branches at irregular intervals (Ksiażkiewicz, 1977). Although the closely related graphoglyptid ichnogenus Paleodictyon Menegheni, 1850 has previously been reported from strata (Grog Brook Group) of the Matapedia Basin (Pickerill, 1980, 1987), Megagrapton, until now, has never been recorded. The ichnogenus is a typical deep-water form.

Ichnogenus Monocraterion Torell, 1870

\section{Monocraterion ichnosp.}

(Fig. 2f)

\section{Description}

Five specimens, each preserved as a series of spherically or sub-spherically arranged laminae on upper and lower surfaces of thinly-bedded calcareous fine-grained siltstones. On upper surfaces the overall diameter of the essentially circular structures may attain a maximum of $20 \mathrm{~mm}$ and on lower surfaces the diameter of the corresponding trace is considerably reduced; thus, individual specimens consist of a funnel-like arrangement of laminae. Whether the funnels are concordant or discordant with respect to the laminae (terminology of Crimes et al., 1977) cannot be ascertained due to the thin nature of the siltstone slabs; however, vertical sections clearly indicate sediment disturbance and downward tapering. The thin slabs also precluded any observation of associated vertical pipe structures which, ideally, but not universally (see Fillion and Pickerill, in press b), should extend downward from the funnels. Funnel depth is at least $7 \mathrm{~mm}$ in one example but preservation is typically incomplete.

\section{Remarks}

Although incompletely preserved, the downward tapering of the funnels distinguishes the specimens from the morphologically similar trace fossils (when observed only in planes parallel to stratification) Cylindrichnus Howard, 1966 and Laevicyclus Quenstedt, 1879. The ichnogenus Rosselia Dahmer, 1937 also exhibits a similar morphology in plane section but is character- ized by a central pipe penetrating the funnel. Because of the generally poor and incomplete preservation of the Matapedia material it is only identified at the ichnogeneric level. Although Clausen and Vilhjálmsson (1986) recently suggested that Monocraterion should be regarded as a junior synonym of Skolithos Haldeman, 1840, we follow the recommendation of Fillion and Pickerill (in press b) to retain the ichnogenus (see also Crimes et al., 1977). Though commonly and more typically reported from neritic sequences, Monocraterion has also been previously reported from deep-water environments by, for example, Jordan (1981) and MacDonald (1982).

\section{Ichnogenus Phycosiphon Fisher-Ooster, 1858}

\section{Phycosiphon incertum Fisher-Ooster, 1858}

(Fig. 3a)

\section{Description}

Horizontal, small U-shaped looped burrows that connect to adjacent $U$-shaped loops to give the trace an overall antler-like appearance. Burrow diameter is 1-2 mm, consistent within individual systems; loop length variable, up to $9 \mathrm{~mm}$ but typically 4-7 $\mathrm{mm}$. Burrow fill is finer grained and is darker in colour than the enclosing fine-grained siltstone. Individual loops do not possess a spreite between their arms.

\section{Remarks}

Although lacking a spreite, the material can confidently be assigned to $P$. incertum. Indeed, the majority of figured examples of $P$. incertum (e.g., Häntzschel, 1975, Chaplin, 1980; Marintsch and Finks, 1982, Bjerstedt, 1987) similarly do not possess a spreite. The recording of $P$. incertum from the Matapedia Group at Tobique represents the first from the Matapedia Basin. Although a eurybathic form, the trace is more commonly reported from deep-water flysch sequences.

\section{Ichnogenus Rusophycus Hall, 1852}

\section{Rusophycus didymus (Salter, 1856)}

(Fig. 3b)

\section{Descrintion}

Four specimens, preserved in convex hyporelief on the sole of a fine-grained siltstone/shale bed. Each consists of a poorly preserved and only slightly elongate, bilobed, shallow impression, 4-5 $\mathrm{mm}$ in total maximum width and 4-6 $\mathrm{mm}$ in length, individual lobes being separated by a narrow $(<1 \mathrm{~mm})$ but distinct furrow which runs the entire length of the lobes. Individual lobes are parallel and generally smooth, though one specimen displays a hint of very fine transverse striations on one lobe. The four specimens all exhibit a similar orientation suggestive of rheotaxis and are associated with miscellaneous and unidentified arthropod markings. 

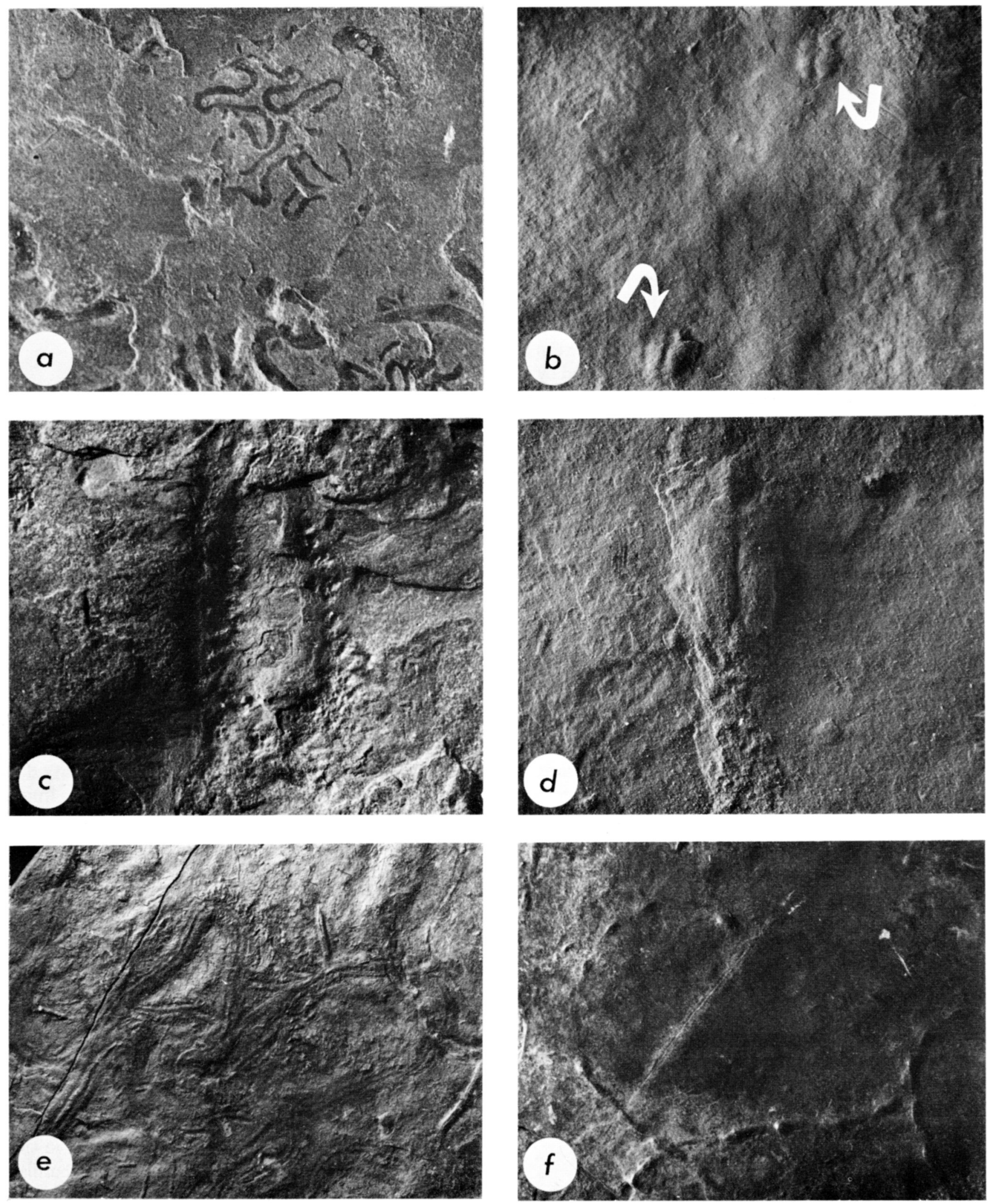

Fig. 3. a.Phycosiphon incertum preserved in epirelief on an upper bedding plane surface, $x 2.0$. b. Rusophycus didymus (arrowed) preserved in convex hyporelief, x1.5. c. Rusophycus ichnosp. type A preserved inconvex hyporelief, x1.4. d. Rusophycus ichnosp. type B preserved in convex hyporelief, x1.6. e. Scolicia ichnosp. preserved in convex hyporelief, x0.6. f. Tuberculichnus ichnosp. preserved in convex hyporelief, x1.0. 


\section{Rusophycus ichnosp. type A}

(Fig. 3c)

\section{Description}

One specimen, poorly preserved in convex hyporelief on the sole of a fine-grained siltstone layer. The specimen is very shallowly impressed, bilobed, but posteriorly tapering, $2.5 \mathrm{~cm}$ in preserved length, and $1.7 \mathrm{~cm}$ in maximum width towards the anterior extremity. Individual lobes are only observed towards their external margins; thus, no central furrow as such can be observed though the sediment is more depressed where the furrow would have existed had preservation been better. The lobes possess crudely developed and irregularly spaced ridges oriented normal to the external margins of the lobes themselves.

\section{Rusophycus ichnosp. type B}

(Fig. 3d)

\section{Description}

Single specimen, preserved in convex hyporelief on the sole of a coarse-grained siltstone slab. The trace consists of a bilobed elongate impression, $15 \mathrm{~mm}$ long, $8 \mathrm{~mm}$ in maximum width and slightly tapering posteriorly. Lobes are smooth, moderately impressed and separated by a clearly defined, narrow $(<1 \mathrm{~mm})$ median furrow. A small $3 \mathrm{~mm}$ long enigmatic ridge protrudes from the anterior end of the central furrow.

\section{Remarks}

Of the six specimens of Rusophycus identified from the material, four can be confidently assigned to $R$. didymus, which in all probability is the resting impression made by the same arthropod responsible for the production of Cruziana problematica. Because of their poor preservation the two other specimens can only be identified at the ichnogeneric level; however, they are clearly different from $R$. didymus and differ from each other. Thus, they are herein described simply as Rusophycus ichnosp. type A and Rusophycus ichnosp. type B. The latter ichnospecies somewhat resembles $R$. pudicum, particularly with respect to its overall shape, but this may be a preservational artefact. $R$. didymus has previously been reported from nonmarine and shallow-marine environments (e.g., Seilacher, 1955; Pickerill and Forbes, 1979) but, to our knowledge, never from a deep-water marine slope sequence.

\section{Ichnogenus Scolicia de Quatrefages, 1849}

\section{Scolicia ichnosp.}

(Fig. 3e)

\section{Description}

Two samples, preserved in convex hyporelief on the soles of thinly interbedded siltstone and slate. Each trace consists of a bilaterally symmetrical, irregularly meandering, $7 \mathrm{~mm}$ wide marking consisting of two well-defined lobes, each $3 \mathrm{~mm}$ wide, separated by a $1 \mathrm{~mm}$ wide ridge, which periodically changes into a furrow and then back into a ridge at irregular intervals along the length of the trace. Lobes are typically smooth but in places possess delicate and closely spaced transverse striations, which cut across the entire lobe surface. External margins of the lobes are clearly defined, and in some places are characterized by slightly elevated and thin marginal ridges, though these are not developed along the whole course of the trace.

\section{Remarks}

The ichnogenus Scolicia is a morphologically variable and complex form with many preservational variants and is clearly in need of serious and monographic taxonomic revision (Howard and Frey, 1984). Even the material described herein exhibits morphological change within a single trace. For these reasons the material is only identified at the ichnogeneric level and the reader is referred to Chamberlain (1971), Ksiażkiewicz (1977) and Smith and Crimes (1983) for more extensive discussions on the nature, origin and morphological variations of the traces. The recording of the facies-crossing trace fossil Scolicia is its first from the Matapedia Basin.

\section{Ichnogenus Tuberculichnus Ksiạzkiewicz, 1977}

\section{Tuberculichnus ichnosp.}

(Fig. 3f)

\section{Description}

Six specimens, each consisting of irregularly shaped and different sized ridges, pods or tubercles of sediment preserved as positive features in convex hyporelief on the soles of fine-grained sandstones. The pods or tubercles tend to be elongate, up to $8 \mathrm{~mm}$ in length and $5 \mathrm{~mm}$ in width and are arranged in freely winding, loosely meandering or spiralled rows, individual pods being separated by intervals of undisturbed sediment which vary in length from 1-9 mm. Individual pods are smooth and fill is identical in grain size to enclosing sediment.

\section{Remarks}

Ksiązikiewicz (1977) erected three ichnospecies of Tuberculichnus, namely $T$. vagans, $T$. meandrinus and $T$. bulbosus, from the Mesozoic flysch of the Polish Carpathians. The diagnoses, descriptions and variations exhibited by each of these are, unfortunately, incomplete but were apparently based on "...the shape and alignment of tubercles..." (Ksiąikiewicz, 1977, p. 140). The ichnospecies $T$. vagans and T. meandrinus exhibit considerable overlap with respect to these parameters and a re-study of Ksiazkiewicz's material seems necessary. For this reason the material described herein is only identified at the ichnogeneric level. Ksiazkiewicz (1977) interpreted T. vagans as a full burrow and this seems likely for our own material, the distinctive pods simply representing interface portions of a vertically- and horizontally-meandering burrow system similar to that recently 
described by Crimes and Anderson (1985) for Hormosiroidea canadensis. The recording of Tuberculichnus from the Matapedia Group represents its first outside of the Polish Carpathians.

\section{COMMENTS, DISCUSSION AND CONCLUSIONS}

The described specimens numerically represent an extremely low proportion of the collected material $(<5 \%)$, and can generally be regarded as rare forms. Given the industrious sampling procedures, their presence is significant in several respects.

First, their discovery emphasizes the necessity of thorough and detailed sampling procedures (cf. Pickerill, 1980) at single fossiliferous sites, before conclusions are made regarding diversity, stratigraphic distribution, etc., of the various taxa. Indeed, the 9 ichnogenera (12 ichnospecies) reported herein (Circulichnis, Cruziana, Diplichnites, Megagrapton, Monocraterion, Phycosiphon, Rusophycus, Scolicia and Tuberculichnus) represent a considerable addition to the 13 ichnogenera (15 ichnospecies) previously reported from the same site by Pickerill $e t$ al. (1987) (Cochlichnus, Dictyodora, Dimorphichnus, Glockerichnus, Gordia, Helminthopsis, Muensteria (=Taenidium), Neonereites, Nereites, Palaeophycus, Syncoprulus and Yakutatia). These latter ichnogenera are all present in the new material and in approximately the same proportions as previously documented (see Pickerill et al., 1987). No additional comments on this material are considered necessary, except perhaps to note that a single slab exhibited gregarious Yakutatia emersoni, never previously noted with respect to this ichnospecies.

Second, of these 9 newly discovered ichnogenera, none have been previously reported from the Matapedia Group of the Matapedia Basin of Fyffe et al. (1981), although Diplichnites has been previously described from coeval strata of the Siegas Formation of the same basin by Pickerill (1981). The other major older and partially coeval stratigraphic unit of the Matapedia Basin, the Grog Brook Group of St. Peter (1977), although itself relatively diverse with respect to trace fossil ichnogenera (see Pickerill, 1987), also contains none of the presently described forms.

Third, of these 9 ichnogenera, only Megagrapton is a typical deep-water form. Circulichnis, Phycosiphon, and Scolicia are facies-crossing ichnotaxa, while Tuberculichnus has only previously been recorded in the flysch of the Polish Carpathians (Ksiażkiewicz, 1977) and therefore further comment is not warranted. Yet Cruziana, Diplichnites, Monocraterion and Rusophycus are typical shallow-water forms. Of these latter forms, rare occurrences of Diplichnites and Monocraterion have previously been noted in deep-water strata (see systematic ichnology), but to our knowledge Cruziana and Rusophycus have only previously been recorded from non-marine and shallow marine sequences (see also Crimes, 1977). The occurrence of more typically shallow-water ichnotaxa in deep-water flysch of the Matapedia Group somewhat recalls the reverse situation recently reported by Crimes and Anderson (1985) from the Upper Precambrian-Lower Cambrian Chapel Island and Random formations of southeastern Newfoundland. These authors reported several more typical deep-water ichnotaxa (including Helminthoida, Paleodictyon, Protopaleodictyon and Squamod- ictyon) from shallow subtidal strata occurring in association with many more typically shallow-water ichnotaxa. It appears likely, therefore, that in the Early Palaeozoic similar ichnotaxa could be produced in different environments so that most should be regarded as facies-crossing; thus, extreme caution must be exercised in utilizing such ichnotaxa as facies or environmental indicators. Studies on the types and evolutionary development of trace fossils in deep-water Lower Palaeozoic flysch sequences are currently under investigation by one of us (R.K.P.).

Fourth, the additional 9 ichnogenera now extend the overall diversity of ichnotaxa at the Tobique site to 22 ichnogenera (27 ichnospecies). We have already previously commented on the fact that this site preserves the most diverse slope ichnocoenosis reported to date and the additional ichnogenera reported herein further reinforce this conclusion. It seems likely that the Phanerozoic trace fossil diversity models of Seilacher $(1974,1977 \mathrm{~b})$ and Frey and Seilacher (1980), which predict diversities of 4-8 ichnospecies for Ordovician and Silurian flysch, are in need of serious revision. Rather, it is our experience that deep-sea trace fossil diversities in Ordovician and Silurian strata may show a broad range (cf. Benton, 1982a). Thus, for example, Benton (1982a,b) records 3 and 20 ichnospecies from, respectively, the Ordovician of East Germany and the Ordovician and Silurian of Scotland; Seilacher (1974) records 4 ichnospecies from the Ordovician of Iraq and the Silurian of Australia and 8 ichnospecies from the Ordovician of Portugal and the Silurian of Wales; Pickerill $(1981,1987)$ records 16 ichnospecies and ichnogenera from, respectively, Silurian and Ordovician flysch deposits of New Brunswick and Pickerill and Harland (in press) record 9 ichnospecies from flysch slope deposits of the Silurian of northem Greenland (see also Pickerill et al., 1987). Unpublished studies by one of us (R.K.P.) on other Lower Palaeozoic flysch sequences exhibit ichnogeneric diversities of 18 (CambrianOrdovician Meguma Group of Nova Scotia) and 19 (Lower Ordovician Levis Formation of Quebec).

Kitchell et al. (1978) have demonstrated that diversity of biogenic structures in Recent deep-sea environments can vary considerably, the major influence being the presence or absence of surface-grazing organisms rather than depth or nutrient supply per se. Despite the fact that their observations were made primarily on surface-produced structures and they had no means of sampling the infaunal graphoglyptids of Seilacher (1977a), their conclusions do provide a cautionary note that even in the Recent, deep-sea diversities can be varied. Thus, it is likely that a true picture of Early Palaeozoic deep-sea trace fossil diversity cannot be obtained simply by plotting totals for various flysch formations (Benton, 1982a) and that the real patterns are masked by sampling biases and local environmental and preservational factors.

\section{ACKNOWLEDGEMENTS}

We wish to thank the New Brunswick Department of Natural Resources and Energy for providing the minority group summer contract to Donna and Regina Pearly. D. Fillion is thanked for his comments on an initial version of the manuscript and Barry Cameron and Hans Hofmann are thanked for providing construc- 
tive reviews. D. Tabor prepared the manuscript and technical assistance was provided by T. Leonard and R. McCulloch. The work was completed with the aid of Natural Sciences and Engineering Research Council of Canada, Grant A3857 to R.K. Pickerill, which is gratefully acknowledged.

BENTON, M.J. 1982a. Dictyodora and associated trace fossils from the Palaeozoic of Thuringia. Lethaia, 15, pp. 115-132.

1982b. Trace fossils from Lower Palaeozoic ocean-floor sediments of the Southern Uplands of Scotland. Transactions of the Royal Society of Edinburgh, 73, pp. 67-87.

BJERSTEDT, T.W. 1987. Latest Devonian-earliest Mississippian nearshore trace-fossil assemblages from West Virginia, Pennsylvania, and Maryland. Joumal of Paleontology, 61, pp. 865-889.

BROMLEY, R.G. and ASGAARD, U. 1979. Triassic freshwater ichnocoenoses from Carlsberg Fjord, east Greenland. Palaeogeography, Palaeoclimatology, Palaeoecology, 28, pp. 39-80.

CHAMBERLAIN, C.K. 1971. Morphology and ethology of trace fossils from the Ouachita Mountains, southeastern Oklahoma. Journal of Paleontology, 45, pp. 212-246.

CHAPLIN, J.R. 1980. Stratigraphy, trace fossil associations and depositional environments in the Borden Formation (Mississippian), northeastern-Kentucky. Kentucky Geological Society, Annual Fall Field Trip Guidebook. Kentucky Geological Survey, Lexington, Kentucky, 114 p.

CLAUSEN, C.K. and VILHJÁLMSSON, M. 1986. Substrate control of Lower Cambrian trace fossils from Bomholm, Denmark. Palaeogeography, Palaeoclimatology, Palaeoecology, 56, pp. 5168.

CRIMES, T.P. 1977. Trace fossils of an Eocene deep-sea sand fan, northem Spain. In Trace fossils 2. Edited by T.P. Crimes and J.C. Harper. Geological Joumal Special Issue 9. Seel House Press, Liverpool, pp. 71-90.

CRIMES, T.P. and ANDERSON, M.M. 1985. Trace fossils from Late Precambrian-Early Cambrian strata of southeastern Newfoundland (Canada): temporal and environmental implications. Journal of Paleontology, 59, pp. 310-343.

CRIMES, T.P., LEGG, I., MARCOS, A., and ARBOLEYA, M. 1977. ?Late Precambrian-low Lower Cambrian trace fossils from Spain. In Trace fossils 2. Edited by T.P. Crimes and J.C. Harper. Geological Journal Special Issue 9. Seel House Press, Liverpool, pp. 91-138.

DAHMER, G. 1934. Die Fauna der Seifener Schlichten (Siegenstufe). Abhandlungen der Preubischen Geologischen Landesanstalt Neue Folge, 147, $91 \mathrm{p}$.

FILLION, D. and PICKERILL, R.K. 1984. Systematic ichnology of the Middle Ordovician Trenton Group, St. Lawrence Lowland, eastern Canada. Maritime Sediments and Atlantic Geology, 20, pp. 1-41.

- In press a. Ichnology of the upper Cambrian(?) to lower Ordovician Bell Island and Wabana groups of eastern Newfoundland. Palaeontographica Canadiana.

- In press b. Comments on substrate control of Lower Cambrian trace fossils from Bomholm, Denmark. Palaeogeography, Palaeoclimatology, Palaeoecology.

FREY, R.W. and SEILACHER, A. 1980. Uniformity in marine invertebrate ichnology. Lethaia, 13, pp. 183-207.

FURSICH, F.T. 1974. On Diplocraterion Torell, 1870 and the significance of morphological features in vertical, spreiten-bearing, U-shaped fossils. Joumal of Paleontology, 48, pp. 952-962.

FYFFE, L.R., PAJARI, G.E., and CHERRY, M.E. 1981. The Acadian plutonic rocks of New Brunswick. Maritime Sediments and
Atlantic Geology, 17, pp. 23-36.

HÄNTZSCHEL, W. 1975. Trace fossils and Problematica. In Treatise on Invertebrate Paleontology. Part W. Edited by C. Teichert. Geological Society of America and University of Kansas Press, Kansas Press, Boulder, Colorado, Lawrence, Kansas, 269 p.

HOWARD, J.D. and FREY, R.W. 1984. Characteristic trace fossils in nearshore to offshore sequences, Upper Cretaceous of east-central Utah. Canadian Journal of Earth Sciences, 21, pp. 200-219.

JORDAN, T.E. 1981. Enigmatic deep-water mechanisms, upper part of the Oquirm Group, Utah. Journal of Sedimentary Petrology, 51, pp. 879-894.

KITCHELL, J.A., KITCHELL, J.F., JOHNSON, G.L., and HUNKINS, K.L. 1978. Abyssal traces and megafauna: comparison of productivity, diversity and density in the Arctic and Antarctic. Paleobiology, 4, pp. 171-180.

KSIAZKIEWICZ, M. 1977. Trace fossils in the flysch of the Polish Carpathians. Palaeontologica Polonica, 36, pp. 1-208.

MACDONALD, D.I.M. 1982. Palaeontology and ichnology of the Cumberland Bay Formation, South Georgia. British Antarctic Survey, Bulletin 57, pp. 1-14.

MARINTSCH, E.J. and FINKS, R.M. 1982. Lower Devonian ichnofacies at Highland Mills, New York, and their gradual replacement across environmental gradients. Journal of Paleontology, 56, pp. 1050-1078.

OSGOOD, R.G. 1970. Trace fossils of the Cincinnati area. Palaeontographica Americana, VI (41), pp. $281-444$.

OSGOOD, R.G. and DRENNEN, W.T. 1975. Trilobite trace fossils from the Clinton Group (Silurian) of east-central New York State. Bulletin of American Paleontology, 287, pp. 299-348.

PICKERILL, R.K. 1980. Phanerozoic flysch trace fossil diversityobservations based on an Ordovician flysch ichnofauna from the Aroostook-Matapedia Carbonate Belt of northem New Brunswick. Canadian Journal of Earth Sciences, 17, pp. 1259-1270.

. 1981. Trace fossils in a Lower Palaeozoic submarine canyon sequence - the Siegas Formation of northwestem New Brunswick, Canada. Maritime Sediments and Atlantic Geology, 17, pp. 37-58. - 1987. Late Ordovician sedimentary rocks and trace fossils of the Aroostook-Matapedia Carbonate Belt at Runnymede, Restigouche River, northem New Brunswick. In Northeastern Section of the Geological Society of America, Centennial Field Guide Volume 5. Edited by D.C. Roy. Geological Society of America Incorporated, pp. 385-388.

PICKERILL, R.K. and FORBES, W.H. 1979. Ichnology of the Trenton Group in the Quebec City area. Canadian Joumal of Earth Sciences, 16, pp. 2022-2039.

PICKERILL, R.K. and HARLAND, T.L. In press. Trace fossils from Silurian slope deposits, North Greenland. Gronlands Geologiske Undersogelse, 13.

PICKERILL, R.K., FYFFE, L.R., and FORBES, W.H. 1987. Late Ordovician-Early Silurian trace fossils from the Matapedia Group, Tobique River, westem New Brunswick, Canada. Maritime Sediments and Atlantic Geology, 23, pp. 77-88.

SEILACHER, A. 1955. Spuren und Lebensweise der Trilobiten. In Beiträge zur Kenntnis des Kambriums, in der Salt Range (Pakistan). Edited by O.H. Schindewolf and A. Seilacher. Akademie der Wissenschaften und der Literatur zu Mainz, matematisch-naturwissenschaftliche Klasse, Abhandlungen 10, pp. 86-116.

1974. Flysch trace fossils: Evolution of behavioural diversity in the deep-sea. Neues Jahrbuch fur Geologie und Palaontologie Monatschefte 1974, pp. 233-245.

. 1977a. Pattern analysis of Paleodictyon and related trace fossils. In Trace fossils 2. Edited by T.P. Crimes and J.C. Harper. 
Geological Journal Special Issue 9, Seel House Press, Liverpool, pp. 289-334.

1977b. Evolution of Trace Fossil Communities. In Pattems of Evolution as illustrated by the fossil record. Edited by $\mathrm{A}$. Hallam. Developments in palaeontology and stratigraphy, 5, pp. 359-376.

SMITH, A.B. and CRIMES, T.P. 1983. Trace fossils formed by heart urchins - a study of Scolicia and related traces. Lethaia, 16, pp. 79 92.
ST. PETER, C. 1977. Geology of parts of Restigouche, Victoria, and Madawaska counties, northern New Brunswick. Mineral Resources Branch, Department of Natural Resources, New Brunswick. Report of Investigation, 17,69 p.

TREWIN, N.H. 1976. Isopodichnus in a trace fossil assemblage from the Old Red Sandstone. Lethaia, 9, pp. 29-37. 